\title{
Condições de produção e difusão do personagem Zé Povo no Brasil: um estudo sobre caricaturas políticas na revista ilustrada O Malho (1900-1910)
}

\author{
The conditions of production and diffusion of the character Zé Povo in Brazil: a study on \\ political caricatures in O Malho illustrated magazine (1900-1910)
}

\author{
Janine Figueiredo de Souza Justen \\ Doutora em Comunicação e Cultura UFRJ \\ janine.justen@gmail.com
}

\author{
Maurício Izelli Doré \\ Doutorando em Sociologia - UFS \\ mauricioizelli@gmail.com
}

\begin{abstract}
Resumo: Este artigo investiga as condições de produção e difusão das revistas ilustradas na cidade do Rio de Janeiro na virada do século XX e o papel dessa imprensa na construção da identidade nacional brasileira. A hipótese aponta para o desempenho de um papel decisivo no processo tanto dos espaços de circulação dos agentes envolvidos, quanto das dinâmicas de importação de valores estéticos, modelos gráficos e técnicas de impressão europeias. Nesse contexto, a emergência do Zé Povo e sua reprodução massiva em caricaturas políticas e de costumes é exemplar. São acionadas trajetórias escolares e profissionais dos agentes para uma análise de redes, assim como instâncias de consagração e militância para uma análise de correspondências múltiplas (ACM). Os resultados indicam relações estreitas entre Brasil e Portugal na formação das "elites culturais" e uma não especificação da ocupação "caricaturista", que transitava entre os campos da arte, dos intelectuais e da política naquele contexto.
\end{abstract}

Palavras-chave: revistas ilustradas, identidade nacional, Zé Povo.

\begin{abstract}
This paper debates the conditions of production and diffusion of the illustrated magazines in the city of Rio de Janeiro at the turn of the 20th century and, on the other hand, the role of this press fraction in the construction of the Brazilian national identity. The hypothesis points to the espaces of circulation of the agents and the import dynamics of European aesthetic values, graphic models and printing techniques as an important and decisive issue to the development of that processus. In this context, the emergence of Zé Povo and your massive reproduction at political and customs caricatures is exemplary. The scholar and professional trajectories of the agents were considered, as well your consecrated instances and militancy for a network analysis and a multiple correspondence analysis (MCA). The results indicate a stronger relation between Brazil and Portugal in the formation of "cultural elites" and a non-specification of the "caricaturist" occupation, which, in the period, transited between the fields of art, intellectuals and politics.
\end{abstract}

Keywords: illustrated magazines, national identity, Zé Povo. 


\section{Introdução}

Este artigo investiga as condições de produção e difusão do personagem Zé Povo enquanto representação de uma identidade nacional brasileira na revista ilustrada O Malho (1900-1910), cuja maior fatia dos exemplares era dedicada a charges e caricaturas (cerca de $65 \%$ do total da publicação, para o período analisado). Consideradas parte integrante da produção de caricaturas políticas na cidade do Rio de Janeiro, em um contexto chave da história inicial da República, essas imagens e seus autores são analisados em relação aos espaços de formação e socialização em questão e, também, em relação aos processos de legitimação da linguagem gráfica adotada.

Com frequência, na história da imprensa brasileira, a evolução das revistas ilustradas é associada ao movimento dos intelectuais, sobretudo daqueles republicanos e modernistas que enxergaram, na produção e na reprodução de imagens, oportunidade de construir novos símbolos de identidade nacional contrapondo, por exemplo, a figura do índio romântico de José de Alencar, estampada nos enredos de $O$ Guarani (1857) e Iracema (1865), a arquétipos mais relacionados às ideias de progresso e urbanidade, ainda que preservados alguns aspectos da tradição.

À época, o mercado editorial apresentava-se como alternativa de trajetória profissional real às “carreiras imperiais" (COELHO, 1999), abrangendo para além do exercício do Direito, da Engenharia e da Medicina, a ocupação dos "homens de letras" no universo dos possíveis das empresas de notícias. Esse mercado assumia-se, ademais, um importante canal de visibilidade e/ou acesso para cargos públicos na burocracia do Estado. Os postos oriundos das revistas ilustradas, principalmente aquelas que circulavam nas cidades do Rio de Janeiro e São Paulo e versavam sobre temáticas cotidianas (rotinas da Câmara Municipal, da Prefeitura e do Senado, sátira de costumes e reformas urbano-sanitárias), passaram a recrutar um "círculo de humoristas" especializados na arte da caricatura ou da crônica que se confundia com uma "boemia intelectual" (SALIBA, 2002: 70), dentre os quais podemos citar Angelo Agostini, Rafael Bordalo Pinheiro, Julião Machado, Artur Azevedo, José do Patrocínio, Pardal Mallet, Lúcio de Mendonça, Paula Nei etc.

De maneira geral, aprendiam e reproduziam técnicas de desenho, escrita e impressão a partir das lógicas estéticas europeias, sobretudo francesas, e de seus maquinários litográficos, sobretudo alemães. No entanto, essa não era uma escolha 
arbitrária de importação de modelos, haja vista a posição de centralidade e dominância sobre as produções culturais da época, mas justificava-se através das próprias condições materiais de produção e difusão desses artigos: nossas primeiras revistas ilustradas pensadas, impressas e distribuídas no Brasil - tiveram, majoritariamente, europeus em seus postos de direção, quando não ainda nas etapas anteriores de fundação e elaboração de projetos, formatos e linguagem gráfica, compartilhando espaços de formação, socialização e consagração: Academia de Belas Artes, Grupo do Leão de Ouro, Associação Nacional de Imprensa, Movimento Abolicionista, Partido Republicano, entre outros.

Tem-se que, nas colônias lusófonas do Brasil e da África, as condições de emergência de uma "identidade nacional" foram dependentes das relações culturais estabelecidas entre as dinâmicas de importação e de mediação que conformavam a ambiência desses territórios em comparação à Coroa, implicando uma imposição de identidade expressa pelos "diferentes estados dos campos intelectual e político" (DOS ANJOS, 2003: 583-589). Estavam em jogo disputas políticas, econômicas e culturais sobre a construção de um "projeto civilizador” (BOTELHO, 2005; CARVALHO, 1990, 1987), fosse ele atrelado à manutenção da estrutura aristocrática do domínio da terra e dos títulos de nobreza, estreitamente vinculada à questão da hereditariedade familiar, ou à possibilidade de uma democratização de acesso aos cargos do campo do poder, às instituições de ensino e às chances de mobilidade e ascensão sociais representadas, nesse contexto, pelas bandeiras da universalização do direito, da técnica e do mérito (BORDIGNON, 2016). Essa oposição resultaria em caminhos possíveis para a ruptura do controle da Coroa sobre os chefes locais e para a sua consequente soberania.

Desse modo, a definição da identidade do Zé Povo se insere "num conjunto de práticas de mediação" (DOS ANJOS, 2003: 583) entre os percursos escolares e profissionais dos caricaturistas com passagem anterior pela Europa, com as condições locais de atuação e o contexto político da época. O que nos permite assumir, como hipótese principal deste trabalho, a construção de uma identidade do "povo" no Brasil como sendo um valor tributário das dinâmicas de importação dos princípios iconográficos das revistas ilustradas francesas e portuguesas do fim do século XIX, localizando os modelos estéticos e as condições práticas de um novo "jornalismo popular" - aquele resultante dos processos de industrialização e modernização urbana da Belle Époque - no centro do debate. Considerando que, para Bourdieu (2004: 181), "povo" e "popular" são "alvos que estão em jogo na luta entre os intelectuais" e que, no 
contexto da arte no Brasil, os intelectuais fazem uso das ambiguidades políticas da palavra povo - que pode denotar classes populares, proletariado, nação etc. - para reabilitar uma ideia de popular normalmente associada àquilo que contraria o erudito $\mathrm{e}$ é, portanto, entendido como menor, menos valorizado ou menos autêntico, tem-se que as investidas e ações desses agentes constituem em si forças e disputas nas trajetórias de dominação que carecem de análises mais demoradas.

Para compreender esse fenômeno referimo-nos ao trabalho exploratório conduzido por uma Análise de Correspondências Múltiplas (ACM), a partir da qual pode-se catalogar um total de 682 imagens oriundas de 224 edições d' $O$ Malho datadas entre setembro de 1902 e dezembro de 1906. Essas imagens foram classificadas segundo sua paginação e formato (cor, tamanho, posição, função etc.), assim como por sua autoria (nacionalidade do autor, origem social, posição administrativa na revista, formação e percurso profissional). Em sequência, propõe-se uma análise de redes para identificar e descrever a dinâmica de trocas e circulação entre os artistas e suas instituições de origem no que tange aos espaços de produção das caricaturas e aqueles de formação e ensino.

1

Tradicionalmente, as revistas semanais de variedades, ilustradas ou literárias, são objeto e fonte de pesquisa para a historiografia do jornalismo no Brasil (BARBOSA, 2013, 2010; LUSTOSA, 2005, 1989; LUCA, 2017, 2011; MARTINS, 2019; MARTINS; LUCA, 2008; VELLOSO, 2015, 2010, 1995; LINS, 2010; OLIVEIRA, 2010). As revistas de humor, que constituem um subgrupo das revistas ilustradas e fazem uso irrestrito da caricatura como linguagem gráfica central, foram aquelas com maior expressão no país, principalmente as que circularam na cidade do Rio de Janeiro nas últimas décadas do Império e nas primeiras décadas da República (1880-1920). Essas revistas assumiram posições estratégicas na construção do projeto civilizatório moderno imposto pelas elites políticas, econômicas e culturais (CARVALHO, 1987; BORDIGNON, 2016), das quais podemos citar, a título de exemplificação, O Malho (1902-1954), Fon-Fon! (1907-1958), Tagarela (1902-1904), Careta (1908-1922), Para Todos (1918-1930) etc. De aspirações europeias, principalmente em relação à França e Portugal, as revistas correspondiam a 
possibilidades de acesso aos espaços de consagração e legitimação sociais, além de estabelecerem pontes entre os grupos do pequeno mundo letrado, os dominantes no campo do poder, e o grande público (MICELI, 2015).

Classificada a priori como um saber-fazer marginal, a produção de cunho humorístico manifestava-se "primeiro nos rodapés dos jornais ou em pequenos e efêmeros pasquins semanais, depois nas margens das obras dos próprios autores e, por fim, nas margens da própria produção escrita" (SALIBA, 2002: 38). A associação entre humor e imprensa ganha lugar nas charges, em especial nos jornais mais leves e baratos, daqueles que Olavo Bilac chamava de "verdadeiros espelhos da alma popular" sendo, para os literatos, síntese e análise das opiniões, aspirações e conquistas do povo (SALIBA, 2002: 38). Na indistinção de um "bom" ou de um "mau” riso, característica singular do humor sob a Belle Époque brasileira (1890-1910) (SCHERER, 2012), as narrativas de humor encontraram visibilidade na esfera pública através da produção e do estímulo de estereótipos nacionais. O bom riso, aquele associável a anedotas familiares, de cunho religioso, moralista e, consequentemente, voltado à erudição e à alta cultura, mesclava-se ao mau riso, aquele que indicava escárnio e sátira, normalmente atrelado à noção do grotesco, a uma cultura animalizada e mundana (BAKHTIN, 2010); e os dois juntos davam origem, de maneira difusa, a uma terceira vertente do cômico, essa principalmente "progressista": o riso civilizador ou, dito de outro modo, o riso da ilusão republicana (SALIBA, 2002: 43-66).

Para além do tolerável, da não expressão do rancor ou do direcionamento específico contra algo ou alguém no sentido degradante do vexame e da difamação, esse riso tipicamente moderno passou a ser ferramenta e objeto de discurso de alguns intelectuais engajados na imprensa para alcançar o grande público e, sob a prerrogativa do mercado e da consolidação da atividade em sua dimensão industrial (TELLES, 2010), enquadrar-se na causa da defesa das liberdades individuais. É nesse engajamento político, inclusive, que se encontra a dimensão de autorização do humor na imprensa brasileira, sobretudo no Distrito Federal (SALIBA, 2002: 46-58).

\footnotetext{
${ }^{1}$ Filho de Brás Martins de Guimarães, médico do exército nacional, Olavo Bilac é um caso exemplar da circulação e intersecção entre os campos jornalístico, intelectual e artístico no cenário das revistas ilustradas e literárias no Brasil da virada do século XX. Formado em Medicina pela Faculdade de Medicina do Rio de Janeiro em 1886 e em Direito pela Faculdade de Direito de São Paulo, colaborou com a maioria dos periódicos da época nas cidades de Rio de Janeiro e São Paulo, além de fundar e dirigir ele mesmo, ao lado de Julião Machado (importante caricaturista português) e Mário Pederneiras (irmão do caricaturista brasileiro Raul Pederneiras), as revistas A Cigarra (1895-1896), A Bruxa (1896-1897), O Meio (1889) e A Rua (1910-1927).
} 
Nesse contexto, a questão da construção de uma identidade nacional passa a ser objeto central da disputa pela imposição de um projeto civilizatório no país (BOTELHO, 2005; CARVALHO, 1990, 1987), seja pelo modelo idealista da emergência de um povo enquanto nação, emancipado à medida que unificado, seja, em um segundo momento, pela escolha de uma figura representativa dessa nação, compatível com o cenário de aspirações de uma modernidade urbana na capital. Característica peculiar da representação humorística nos séculos XIX e XX (SALIBA, 2002; FONSECA, 1999; SILVA, 1990), o desenho de ícones na composição dos estereótipos nacionais foi fenômeno global, a julgar pelas figuras de John Bull (Inglaterra), Miguel Alemão (Der Deutsche Michel, Alemanha), Tio Sam (Estados Unidos) etc.

Jurt (2012: 472-481) argumenta que os processos de decadência e ruptura do regime monárquico descorporificaram o poder, uma vez que interromperam as associações entre a figura do rei, da dinastia ou do monarca à ordem vigente e passaram a conectá-lo a regulamentos estatutários desanimados. Essa espécie de orfandade de referências diretas causada pelo "anonimato do poder democrático" implicaria a necessidade de, na República, se eleger símbolos coletivos, como em uma comunidade política, na intenção de fazer valer a potência e o direito de um "poder sem corpo".

No Brasil, a referência à nação fora estritamente ligada ao Estado no contexto pós-Independência, já que não havia se constituído aqui, por enquanto, uma ampla consciência nacional; as elites políticas e econômicas, especialmente aquelas urbanas não definidas pela posse de títulos de nobreza, teriam, então, o maior interesse em construir uma nova ordem simbólica apta a exprimir um conjunto de valores através do qual pudessem se enxergar nele refletidos (JURT, 2012; CARVALHO, 2008).

Considerando as origens sociais dos agentes que compunham as "elites políticas" e os "homens de letras", os artistas e os intelectuais, temos que: no primeiro universo, predominam os filhos de "proprietários" (44,2\%) e de "oficiais militares" (21\%); no segundo universo, predominam os filhos de "proprietários" (37\%) e de "funcionários públicos, pequenos proprietários e artesãos" (23,9\%), correspondendo às camadas sociais mais baixas (BORDIGNON, 2014: 8-10). Grosso modo, seria a configuração do segundo universo aquela correspondente a do grande grupo dos republicanos, que reuniriam a defesa de pautas relacionadas aos direitos políticos e econômicos, resultando na ampla adesão ao abolicionismo, por exemplo, e pautas pela 
reconfiguração dos mecanismos de acesso aos espaços de circulação e socialização das redes de poder antes legitimados nas relações pessoais e familiares.

A prerrogativa do direito universal, importado das revoltas liberais européias, especialmente da Revolução Francesa ${ }^{2}$, formaliza novos princípios de distinção social a partir de critérios derivados da técnica e do mérito, materializados nas "certificações formais de competência", isto é, nos "títulos escolares, reconhecimento pelos pares e concursos" (BORDIGNON, 2016: 244). No entanto, foram mantidos os cenários de concentração de renda e de recursos nas redes das elites políticas; o poder oligárquico se reproduziu apoiado na manutenção das altas taxas de analfabetismo e nos baixíssimos indicadores de acesso às esferas de ensino no país: em 1872 e 1890, respectivamente, as taxas de analfabetismo eram de $82,3 \%$ e $82,6 \%$; em 1920, 71,2\% para população de 5 anos ou mais e 64,9\% para população de 15 anos ou mais (FERRARO, 2002 apud BORDIGNON, 2014). Com relação ao acesso aos níveis de ensino secundário e superior temos, para o período de 1872 a 1940, abrangendo o último quarto do Império e toda a Primeira República (1889-1930), taxas de 0,11\% e 0,01\%, respectivamente ${ }^{3}$.

Os periódicos de variedades, sobretudo as revistas ilustradas, compunham, a inserção de novas práticas e representações no próprio domínio da imprensa, não dividindo-se forçosamente, como de costume, entre os porta-vozes daqueles que estavam no poder e os porta-vozes daqueles que estavam excluídos do poder; formatos esses típicos da imprensa imperial mais panfletária (BARBOSA, 2010; LUSTOSA, 2000; CARVALHO, 2008) ${ }^{4}$. Essa nova vertente da imprensa modificaria até mesmo a relação que os autores mantinham com as suas obras (MICELI, 2015), convertendo-as em uma estrutura particular de consagração, de distribuição e de monetização que tenderia a variar de acordo com o apelo popular. Nessa lógica, ao consagrar os artistas

\footnotetext{
${ }^{2}$ À ocasião da Revolução Francesa formulou-se a equação nação $=$ Estado $=$ povo, sobretudo, povo soberano. Com o avançar do século XIX, concepções acerca de Estado-nação se sobressaem, implicando a emergência de temas como etnicidade, língua comum, religião, território e memória coletiva (BOTELHO, 2005: 322, grifos nossos).

${ }^{3}$ Idem Ibidem.

4 "Os jornalistas lutavam na linha de frente das batalhas políticas e muitos deles eram também políticos. Muitos políticos, por seu lado, escreviam em jornais nos quais o anonimato lhes possibilitava dizer o que não ousariam da tribuna da Câmara ou do Senado. A imprensa era, na verdade, um fórum alternativo para a tribuna [...] D. Pedro II considerava a imprensa um dos principais canais de manifestação da opinião pública" (CARVALHO, 2018: 54).
} 
que a elas se dedicavam, essas revistas se autoconsagravam, repertório bastante comum em cartas e editoriais por elas publicados.

A revista $O$ Malho, tributária dessas classificações porosas de “jornalismo popular" (VISCARDI; SOARES, 2018: 7), trazia em sua proposta editorial a missão de cumprir "um alto dever social" e concorrer "eficazmente para o melhoramento e progresso da raça humana". Para tal, elegera o "povo" como seu interlocutor privilegiado e prometeu, "no meio desse coro fúnebre de tristezas e lamentações", ser alento de riso e com uma blague "dissipar a melancolia geral". Falava em patriotismo e se autorreferenciava o único periódico do mercado capaz de compreender as agruras da "Nação": "Deus não manda mais juízes à terra! Todo esse mal estar, individual e coletivo, que todos e cada um sente [...] só tem uma coisa: - a falta do Malho!"5. À lista das mazelas populares adicionou o delicado cenário financeiro do país, implicando mandados de despejo, a fome, a precariedade na saúde e a narração de más notícias diárias pela imprensa. A figura de Zé Povo, então, cuja história ascende e declina junto à circulação das revistas ilustradas no Brasil, em especial O Malho (1902-1954), Careta (1908-1960) e Fon-Fon! (1908-1958) (SILVA, 1999: 8-9), emerge associada à "ideia de escassa inteligência" e às marcas negativas das "coisas governamentais" na sua vida.

Originalmente sob a assinatura do português Rafael Bordalo Pinheiro (18461905), Zé Povo chega ao Rio de Janeiro em 1877, apenas dois anos depois de sua primeira aparição na revista ilustrada lisboeta Lanterna Mágica (1875); o que se dá em função da mudança de vida do artista, que aceitara um convite de Manuel Rodrigues Carneiro Júnior ${ }^{6}$ para trabalhar no Brasil (LIMA, 1963: 886). Retratada a priori nas páginas do semanário Psit!!! (1877) - onde Bordalo Pinheiro, além de fundador e diretor, assumiu também a posição de único ilustrador do periódico -, o desenho rapidamente tornou-se um sucesso comercial, tendo sido reproduzido inúmeras vezes e constituindo de maneira majoritária o repertório de outros artistas do meio. À época, essas revistas chegaram a alcançar a marca de 100 mil cópias vendidas por mês em uma sociedade cuja soma de iletrados se aproximava dos $80 \%$.

Nesse sentido, como um retrato do perfil da população local, o recenseamento de 1872 - o único produzido no período e, portanto, único registro de fontes oficiais do Império a conter informações sobre a população escravizada (idade, estado civil, grau

\footnotetext{
${ }^{5}$ O Malho, 20 de setembro de 1902 (ano 1, n.1).

6 Proprietário do semanário ilustrado $O$ Mosquito, onde trabalhava Angelo Agostini. À época, esse periódico encontrava-se em grande projeção.
} 
de instrução, ocupação, religião, cor ou "raça" etc.) - estima que 15,2\% do total de habitantes, somando cerca de 1,5 milhão de pessoas, estavam na condição de escravizados (um escravizado para cada seis pessoas livres). Estudos mais recentes (PAIVA; MARTINS 1983; RODARTE; SANTOS JUNIOR, 2019) apontam algumas imperfeições de cálculo que aumentariam drasticamente esse valor como, por exemplo, a não distinção da condição de "escravos libertos" em meio ao grupo de "homens livres": homens e mulheres alforriados de maneira condicional, representando uma prática de "precariedade estrutural da liberdade" (CHALHOUB, 2012), já que tinham seu status de privação de direitos associado ao tempo de vida dos senhores como “demonstração de gratidão" pelo ato de livramento.

A essa amostra somavam-se, ainda, as restrições constitucionais aos direitos políticos (CARVALHO, 1987) e a deficitária inserção de "pessoas livres de cor" (CHALHOUB, 2012) ao espaço das relações mais formais de trabalho, de produção e acumulação de riquezas e de consumo de bens materiais em geral; $62 \%$ da população à época era composta de "não brancos" ou "mestiços", classificada em categorias de "pretos", cuja linhagem familiar era africana, "pardos", filhos de africanos com brancos ou de africanos com "índios", e "caboclos", cuja linhagem familiar era indígena (BOTELHO, 2005). Nesse sentido, os escritores e críticos literários, como Gonzaga Duque (1863-1911) e Monteiro Lobato (1882-1948) ${ }^{7}$, “assinalaram o poder crítico dos desenhos de humor" nas revistas ilustradas, "relacionando-os aos padrões estéticos e culturais próprios a um público pobre e com escasso discernimento artístico" (SILVA, 1990: 8-9). Lima (1963: 119) os relaciona à emergência de uma nova "visualidade humorística", que estaria associada a novos hábitos de informação e lazer decorrentes da renovação urbana do Rio de Janeiro e à difusão dessa imagem. Assim, os caricaturistas atuavam como mediadores culturais entre as altas e baixas classes sociais, sendo ponto de convergência entre o que se convencionou chamar de "cultura erudita" e “cultura popular" (BAKHTIN, 2010), ao passo que traduziam para a elite letrada consumidora o que se passava na relação, nesse caso, entre brancos e negros na sociedade de então; relação que se estende, inclusive, para a expressão das "tensões e conflitos sócio-raciais por espaços no pós-abolição" (SILVA; ALMEIDA, 2013: 324).

\footnotetext{
7 Gonzaga Duque foi uma das figuras mais importantes do simbolismo brasileiro; fundou cinco periódicos, dentre os quais destacam-se Rio-Revistas (1897), Galáxia (1897), O Mercúrio (1901) e FonFon! (1908); teve ainda larga participação como diretor e/ou colaborador de outros títulos na imprensa local. Monteiro Lobato (1882-1948) ganhou prestígio entre os pares e frente ao público sobretudo como escritor e editor; colaborou igualmente em diversos títulos da imprensa no Rio de Janeiro, em São Paulo e no exterior.
} 
Porém, à medida que o caricaturista, enquanto intelectual, passa a ocupar também essa posição de mediador cultural (SILVERMAN, 1977; KUSHNIR, 2001), impõem-se aí disputas pela manutenção desse espaço e da prerrogativa do caricaturista em ocupá-lo. Considerando que o mediador se constitui enquanto aquele que ocupa posições em ambas as estruturas que se conectam, o resultado é o investimento frequente nos temas caros à elite da época (fazendo parte de seu repertório até mesmo a sátira a essa elite) e a projetos intelectuais que ultrapassam as disputas propriamente estéticas do meio artístico (como a construção de um símbolo nacional ou a sátira ao seu projeto). Um segundo resultado é a manutenção da constante dependência em relação às disputas "profanas" (externas ao que seria propriamente artístico ou inerente ao fazer caricatural) e o afastamento das disputas mais codificadas e válidas internamente entre os caricaturistas. Isso porque entendidos como um grupo de características híbridas, articulado entre os campos da arte, dos intelectuais e da política, frequentemente associados a práticas boêmias e, por esse mesmo motivo, frequentemente desqualificados ou menosprezados enquanto categoria (SALIBA, 2002), eram os caricaturistas denegados, de maneira geral, quando em nome institucional/oficioso de alguma disputa de fins consagratórios - neste caso, como apontam Bordignon (2014) e Saliba (2002), os processos de submissão de candidaturas à Academia Brasileira de Letras (ABL) são exemplares ${ }^{8}$.

A importação de modelos europeus de hierarquização e classificação social, com seus esquemas de tipificação ou alegorias sociais (VELLOSO, 2010; BARBOSA, 2013), atravessava o balizamento de instituições e agentes já consagrados entre seus pares e influía sobre as disputas pela afirmação dos papéis e tomadas de posição. Isso implica, portanto, de modo sensível, a importação de técnicas de desenho e impressão, assim como arranjos de conteúdo e formatos gráficos que propagam formas estéticas específicas às percepções sobre a demanda; menos por uma questão de gosto ou distinção, que estaria ligada estritamente ao métier do caricaturista, mais pelo processo de reprodução das dinâmicas de produção conhecidas, experimentadas e legitimadas em seu universo de possíveis.

\footnotetext{
8 Inúmeras foram as candidaturas de Mendes Fradique e Bastos Tigre (1882-1957), colaborador d' $O$ Malho, à ABL; todas recusadas. Emílio de Menezes (1866-1918) e Humberto Campos (1886-s/d) foram os únicos humoristas daquele tempo que conseguiram entrar para a Academia, mesmo trabalhando na "vulgarização" de conteúdos na imprensa. Associam-se com frequência a esses eventos, relações de patronagem e/ou acúmulo de capital social.
} 
Rafael Bordalo Pinheiro, cuja formação em Artes e Letras se dera segundo as diretrizes da Escola Francesa ensinadas na Academia de Belas Artes de Lisboa em 1861, fora inicializado na caricatura cumprindo ritos específicos tanto de ordem técnica (traço, nuances de luz e sombra, técnicas de xilo e litogravura, tipografia etc.) quanto na internalização de princípios classificatórios (hierarquização de temáticas, hierarquização de valores ideológicos, morais e estéticos etc.). Seus espaços de socialização na Europa incluíam a Sociedade Promotora de Belas Artes, da qual era membro desde 1868, e o Grupo do Leão, do qual fora fundador em 1880, ambos portugueses; as Exposições Universais de Paris, que datam desde 1855 e a partir da qual fora nomeado "Cavaleiro da Legião de Honra" na edição de 1889; as restritas galerias de arte francesas, espanholas e portuguesas, onde, em 1871 e 1872, fora premiado pelo desenho "As bodas de aldeia"; o Salão dos Humoristas, em Portugal, cujo pilar erguia-se sobre exposições livres promovidas pela Sociedade Nacional de Belas Artes e outras associações cujo engajamento tratava da liberdade de imprensa, das artes cênicas e da ópera'.

Com relação à sua trajetória profissional, podemos apontar alguns marcos antes de sua chegada ao Rio de Janeiro, das quais destacam-se a passagem pelo semanário panfletário lisboeta A Revolução de Setembro (1869), as revistas ilustradas A Berlinda (1870), O Binóculo (1870) e a já citada Lanterna Mágica (1875), em Portugal; em Madrid, na Espanha, nos semanários de humor Ilustración Española y Americana e El Mundo Cómico, ambos em 1870; na França, L’Univers Illustré; e ainda, no mesmo ano, a importante colaboração em The Illustrated London News, na Inglaterra, periódico apontado por alguns estudiosos (FONSECA, 1999; BACOT, 2002; LUCA, 2017) como dos mais expressivos no mundo à época. A partir de 1877, já em território brasileiro, Bordalo Pinheiro divide o lápis com Angelo Agostini ${ }^{10}$ nas redações de O Mosquito, familiarizando-se com os costumes e exigências da ocupação no país para, então, fundar

\footnotetext{
${ }^{9}$ Levantamento de dados a partir dos acervos da Hemeroteca de Lisboa, do Museu Bordalo Pinheiro e da História da Caricatura no Brasil, de Herman Lima.

${ }^{10}$ Angelo Agostini, italiano de formação europeia, também recebeu educação nas artes e em letras sob o viés francês de qualidade. Chega ao Brasil em 1864, na cidade de São Paulo, para fundar o semanário ilustrado $O$ Diabo Coxo. De perspectiva republicana e abolicionista, funda, em sequência, $O$ Cabrião, $O$ Arlequim e A Vida Fluminense, sendo os dois últimos já no Rio de Janeiro. Trabalhou com Bordalo Pinheiro em $O$ Mosquito ao mesmo tempo em que colaborava com o jornal Cidade do Rio, de José do Patrocínio, fundando a Revista Ilustrada no ano seguinte (MARINGONI, 2010). Especialistas apontam (BARBOSA, 2010, 2013; VELLOSO, 2010; LUCA, 2017; LUSTOSA, 1989, 2005) ser esta uma das publicações ilustradas mais expressivas do Brasil na transição do Império para a Primeira República. Em 1902, Agostini compõe o expediente da revista $O$ Malho, onde colabora com publicações até o momento de sua morte, em 1911.
} 
sua própria revista, Psit!!!, e trazer com ela sua mais popular criação: Zé Povo/Zé Povinho. Era comum, também, que esses artistas do cartum fossem proprietários de suas próprias oficinas litográficas, conferindo facilidades no transporte de maquinário, no emprego da mão de obra e na regulação de qualidade do material, além de reduções significativas no preço de custo da produção.

Os primeiros registros encontrados de Zé Povo fizeram referência estrita à sociedade e à imprensa portuguesas (MEDINA, 2005: 136-139), sendo posteriormente absorvidos pelas publicações de humor no Brasil. O personagem resumiria a imagem reificada de "um nó simbólico de frustrações" a partir de uma vivência de misérias, privações e deficiência estruturais históricas sequenciais; “incapaz de utopizar”, não haveria nele qualquer desejo radical de subversão revolucionária, sendo alheio à política e a todo contexto de decisão pública. Dessa condição, extrai-se seu feitio conformado e conformista, apresentando episódios esparsos de "explosão" quando os homens da lei ou da ordem lhe feriam o bolso com aumentos nas taxas de impostos. "É antiquixosteco e anti-fáustico, ou seja, nega as duas inquietudes europeias mais intensas e trágicas, sendo, por excelência, uma figura não-dramática” (MEDINA, 2005: 139). Destacam-se, ainda, na construção do personagem, as influências do velho Parvo, de Gil Vicente, e Bertoldo e Bertoldinho, da literatura de cordel italiana (figura 1). 
Figura 1: Primeiro registro de Zé Povo

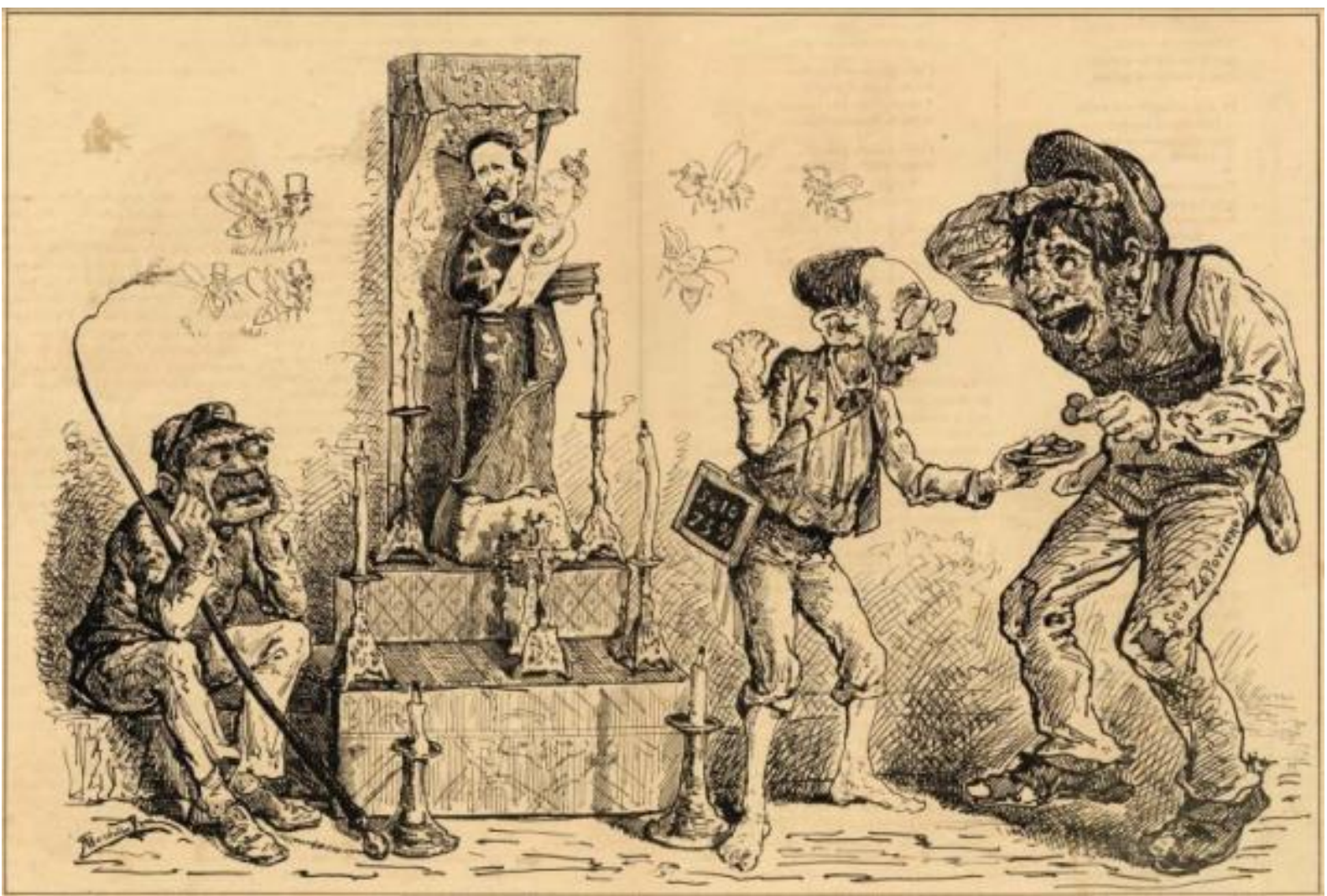

Fonte: Lanterna Mágica, 12 de junho de 1875. Acervo: Hemeroteca de Lisboa.

Já em 1880 (apenas cinco anos mais tarde), entra em circulação na cidade do Porto, Portugal, um semanário ilustrado intitulado Zé Povinho ${ }^{11}$. Daí em diante, a essência de um anti-herói resistente ao setor republicano e positivista dos seguidores de Augusto Comte se diluiria, dando margens a interpretações engajadas interessadas em mobilizar as massas. De origem, no entanto, não tinha em si apelo popular. Em 1877, Zé Povo passa a fulgurar nas páginas d'O Mosquito, no Rio de Janeiro, onde Bordalo Pinheiro assumiu em poucos meses o cargo de diretor artístico, e depois faz-se peça chave dos repertórios de Psit!!! e O Besouro, ambos semanários de propriedade do português. No mesmo ano, Arthur Azevedo escreveu e dirigiu a peça de teatro $O$ Rio de Janeiro em $1877^{12}$, atribuindo ao Zé Povo o papel de protagonista; no ano seguinte, em 1878, Azevedo passou a colaborar com crônicas, poemas e alguns textos de humor n' $O$ Besouro, ao lado de Bordalo e José do Patrocínio, estreitando ainda mais as relações entre as revistas ilustradas, o grupo dos intelectuais e a disputa pela construção de uma

\footnotetext{
11 Informações extraídas do verbete "Zé Povo" da Hemeroteca de Lisboa.

12 A peça, definida pelo autor como "comédia de costumes populares, satírica e burlesca" (AZEVEDO, s/d), contava a história dos esforços pela modernização e pelo progresso na cidade do Rio de Janeiro, evidenciando as situação de higiene, segurança e habitação como fenômenos de "calamidade pública" (id.ib.)
} 
identidade nacional. A primeira aparição de Zé Povo n'O Malho se deu logo no terceiro número da revista, em forma de carta; esta, anônima, seguia endereçada ao então presidente da República Rodrigues Alves, criticando a nomeação de um ministro solteiro:

O conselheiro sabe que o Zé Povo / Não gosta que se entregue uma só pasta / A ministro que seja solteirão. [...] E é sempre assim, o nosso Zé Povinho / Caso a escolha do chefe não recaia / Em casado na igreja ou no civil, / Dirá o mesmo que disse do Murtinho : - Só se apressa a atender rabos de saia / Este homem tão fatídico ao Brasil ( $O$ Malho, 4 de outubro de 1902, grifos $\operatorname{nossos})^{13}$.

O personagem avançou bem cotado nas próximas edições, ocupando cada vez mais espaço em crônicas e versos publicados: "Coitado do Zé Povo! Está ele já habituado a essa exclusão"; "Quanto ao Zé Povo, esse vai sempre no embrulho, contentando-se em gritar - à unha - quando os galos políticos se engalfinham na rinha do paço do Conde de Arcos"14 etc. Como se nota, seguiu reproduzindo a ideia de submissão e da não participação política da versão original portuguesa, o que, segundo Silva (1990: 8), se manteve até 1918, quando o Jeca Tatu caricatural, calcado na criação de Monteiro Lobato, fora retomado frente às manifestações modernistas. "Zé Povo foi apresentado [na imprensa carioca] como lugar de não-poder e de outras carências, dotado da consciência de estar ausente de um poder que invejava e sustentava como aspiração para si” (SILVA, 1990: 17, comentário nosso).

$O$ Malho foi, ainda, a primeira revista ilustrada brasileira (com fundador, proprietário e dirigente brasileiros) a publicar o Zé Povo em formato de charge, sem reproduzi-lo de Bordalo Pinheiro, mas delegando a criação de uma nova versão do personagem a seus cartunistas, com livre traço e interpretação. Em 21 de fevereiro de 1903, assinado por Raul Pederneiras, Zé Povo fora retratado assustado com a postura autoritária do prefeito da cidade do Rio de Janeiro, Pereira Passos, logo após a sua posse (figura 2). Nos anos seguintes, as charges do personagem começariam a ocupar páginas inteiras, até mesmo coloridas, e, por diversas vezes, a capa da revista.

\footnotetext{
13 Joaquim Murtinho fora senador por três mandatos (1890-1896; 1903-1911) e Ministro da Fazenda no governo anterior ao de Rodrigues Alves, durante o mandato do presidente Campos Sales (1898-1902).

${ }^{14}$ O Malho: 23 de novembro de 1902; 10 de janeiro de 1903.
} 


\section{Figura 2: Primeiro registro de Zé Povo n'O Malho (1903)}

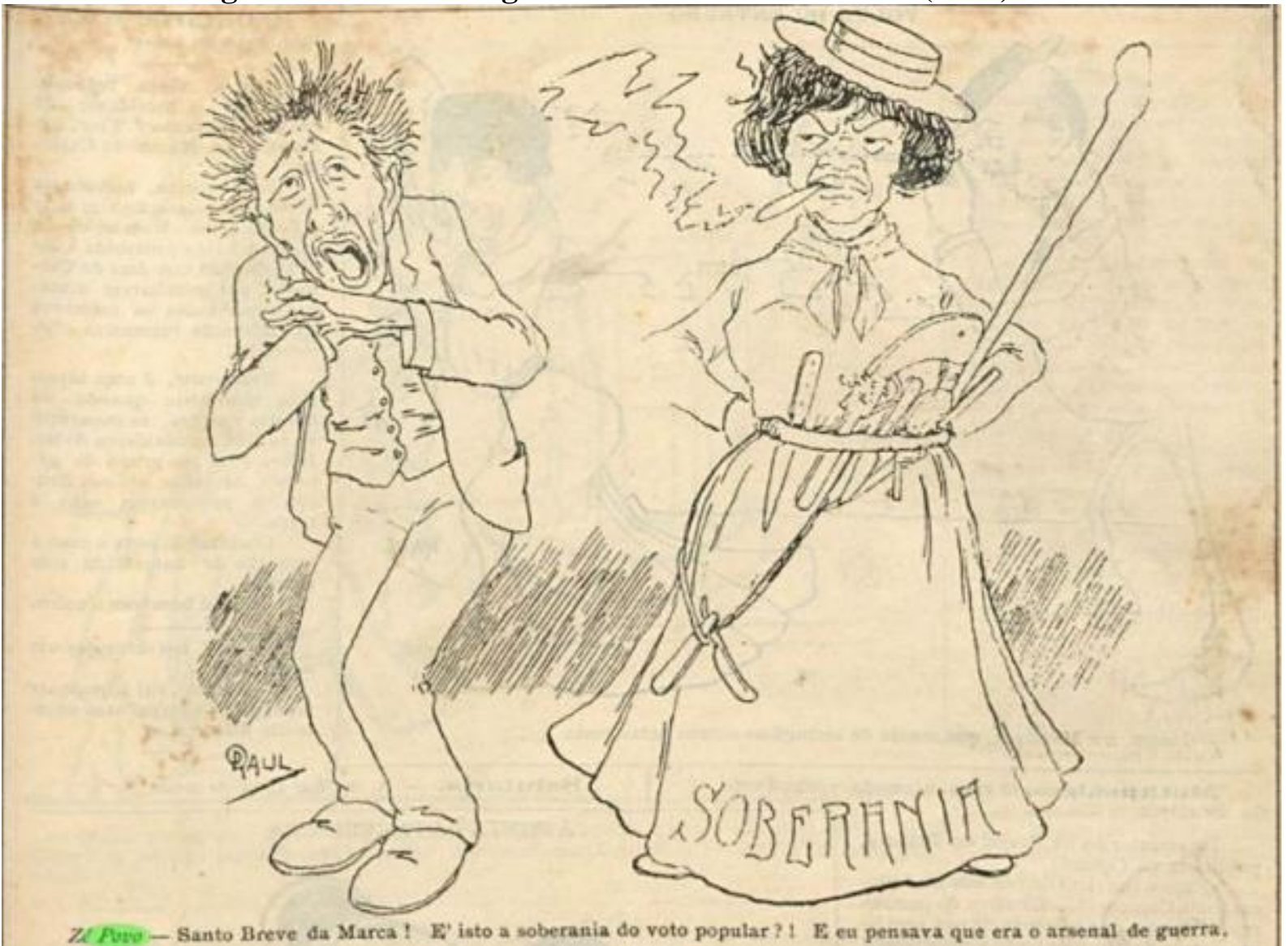

Fonte: O Malho, 21 de fevereiro de 1903. Acervo: Fundação Biblioteca Nacional.

A partir de 1907, Zé Povo já era uma figura familiar da imprensa nacional como um todo, ganhando espaço e coro em outras cidades do país para além do eixo central do Distrito Federal e São Paulo, como Curitiba, na região sul (QUELUZ, 2012), Recife e Salvador, na região nordeste (RIBEIRO, 2010). Na década de 1920, Zé Povo divide o palco das representações com o Jeca Tatu caricatural, inspirado nas obras de Monteiro Lobato, mas já com o governo de Getúlio Vargas, no golpe de estado de 1930, o símbolo retoma a liderança na construção da opinião pública pela imprensa no Brasil (SILVA, 1999: 8), permanecendo em evidência até os anos 1950, quando decaem no país as produções ilustradas de humor.

\section{3}

De influências estéticas normalmente associadas às revistas ilustradas francesas da Belle Époque, principalmente às da segunda metade do século XIX, assim como o 
caráter de sátira e crítica política de suas publicações ${ }^{15}$ (SILVA, 1990; SALIBA, 2002; LIMA, 1963), as condições materiais de produção trazidas de Portugal pelas revistas brasileiras costumam ser negligenciadas pela literatura de referência, mesmo que representem, na prática, a autonomia de produção, reprodução e difusão de exemplares ${ }^{16}$. Em 28 de abril de 1957, por exemplo, um grande jornal de notícias publicava um ofício do Sindicato dos Jornalistas Profissionais do Rio de Janeiro “apresentando congratulações, ao considerar, do lado brasileiro, a grande contribuição dos jornalistas portugueses na formação espiritual da inteligência e da cultura nacionais", dentre os quais destacavam-se os nomes de Julião Machado e Vasco Lima, ambos caricaturistas d'O Malho no período da Primeira República (Correio da Manhã, 28 de abril de 1957).

Mas esse cenário se desenha ainda nas décadas de 1840 e 1850. O período correspondeu às primeiras manifestações mais sólidas de uma produção gráfica industrial (CARDOSO, 2008: 59-62), que ao final desses 10 anos já somava 20 oficinas apenas na cidade do Rio. Levando em consideração o período de importação das primeiras máquinas de litografia (a partir de 1840), "se no Rio de Janeiro havia, em 1844, apenas três estabelecimentos litográficos, em 1875 já havia na cidade 32 oficinas em funcionamento" (BARBOSA, 2013: 169-170). Assim, como ponto central de nossa análise, as condições de produção e difusão de um personagem historicamente ligado ao processo de construção da imagem nacional, o Zé Povo, dependem não somente das condições materiais de impressão e do empreendimento de intelectuais, como da investigação sobre as dinâmicas de importação das referências estéticas que estariam nas bases das possibilidades de difusão desse personagem.

Tomados em conjunto todos os agentes que participaram das edições d'O Malho (caricaturistas, fotógrafos, redatores e dirigentes) e seus espaços de formação incluídos os proprietários dos demais periódicos nos quais esses agentes circularam (gráfico 1), os dados apontam para a emergência desses agentes como centrais no processo de importação e difusão das perspectivas estéticas em pauta. Em analogia ao

\footnotetext{
${ }^{15}$ Le Voleur, La Caricature, Le Charivari, L'Illustration, Le Petit Journal, Journal du Dimanche, Pour Rire etc.

16 Mesmo com a invenção da pedra litográfica em 1796 pelo alemão Alois Senefelder, o período que se estende até os anos 1830 foi marcado, na esfera da caricatura política, por esforços individuais e isolados de artistas majoritariamente membros das elites (KERR, 2000). A ruptura se deu com o surgimento de trabalhos colaborativos, organizados em série e com tiragem regular. A popularização da prática esteve, então, diretamente ligada aos processos e técnicas que permitiram sua produção e reprodução em dimensão industrial, massiva e cadenciada e, portanto, de cunho menos ideológico que de mercado.
} 
campo literário, cujas fronteiras são fluidas e porosas e cujas condições de acesso não são codificadas ou monopolizadas por uma instituição responsável pela distribuição de credenciais, empregamos aqui a análise de redes como ferramenta que nos permite "descrever as estruturas de relações sociais e da circulação de informação e influência" ${ }^{\text {17 }}$ (SAPIRO, 2006: 44-45) no espaço de produção da caricatura. Concebidas como método, e não como teoria social ou caminho para uma "explicação" dos fenômenos, as redes clarificam as posições dos agentes em relação à estrutura do espaço no qual se inserem, evidenciando através dos efeitos das interações, da força, densidade e hierarquização das mesmas a estrutura do quadro social que se quer investigar.

Isso posto, a intenção é partir de tomadas de posição (entendidas como produto de disposições que são, por sua vez, tributárias do acúmulo de recursos desses agentes) para refletir sobre as possibilidades de constituição de determinada rede (SAPIRO, 2006). Assim, nos cabe tecer considerações sobre os elementos que a compõem (grupos e subgrupos) e quais as condições ou disposições que permitem o estabelecimento dessas conexões: é essa análise que nos sensibiliza para a tensão (e assimetria) inerente às relações sociais entre agentes que tenham diferentes condições de acesso aos mesmos recursos, o que indica, por consequência, as chances particulares de acesso aos círculos "de poder" ou "das elites" nos termos dos princípios de dominação (BOISSEVAIN, 1979).

\footnotetext{
17 Do original: "décrir la structures de relations sociales et de la circulation de l'information et de
} l'influence". 


\section{Gráfico 1: Espaços de circulação dos agentes (trajetórias escolares e profissionais)}

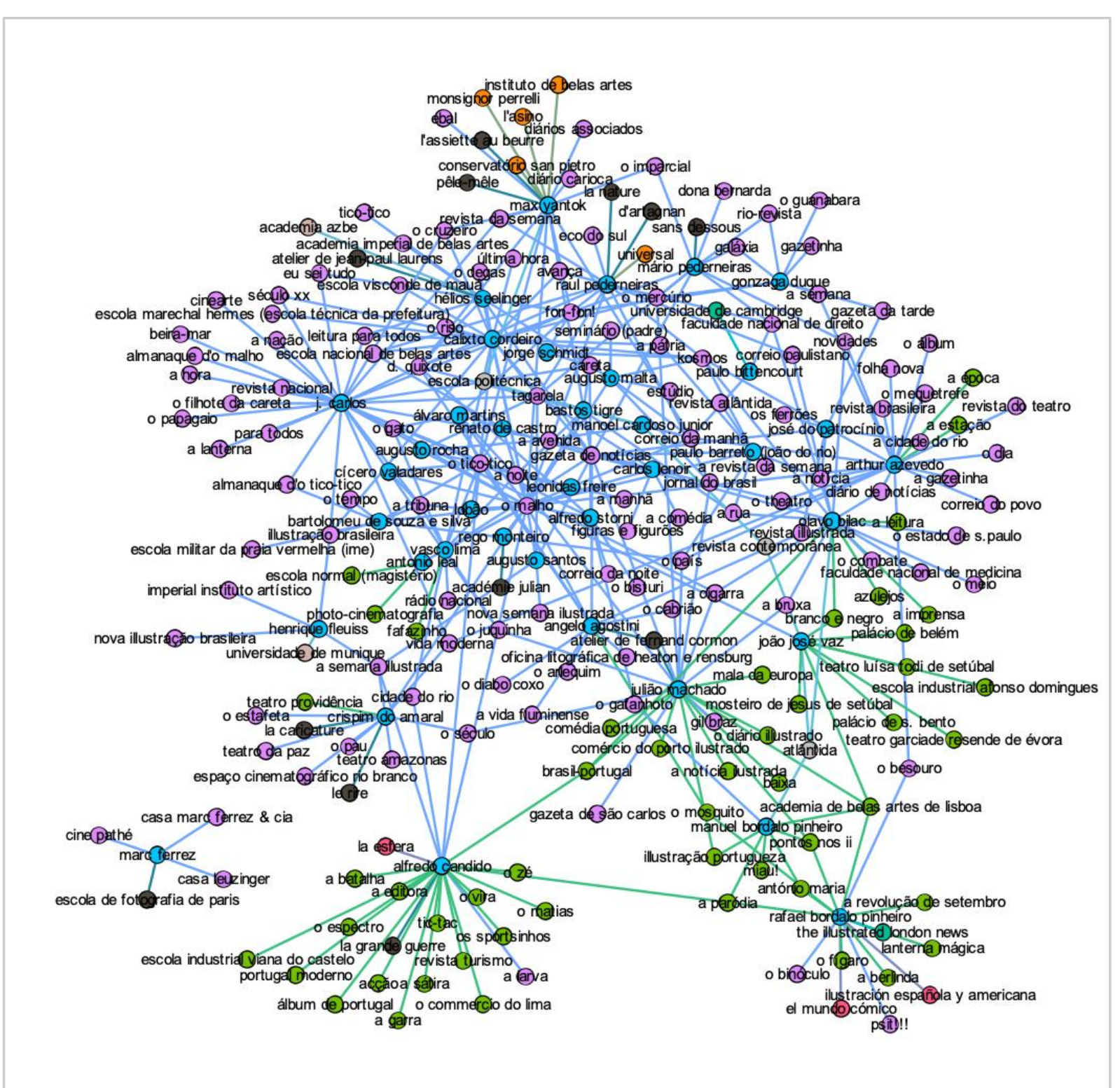

Elaboração dos autores. Software Gephi.

Duas questões emergem a partir da rede, a primeira diz respeito à separação entre instituições e agentes portugueses e aqueles brasileiros. Mais do que uma troca, possivelmente representada por um movimento circular entre agentes e instituições de ambos os países, verifica-se um movimento de portugueses em direção às instituições brasileiras. A segunda questão diz respeito à identificação dos agentes responsáveis pela importação dos referenciais estéticos e os contextos relativos às oportunidades de migração desses agentes que, à exceção de João José Vaz e Manoel Bordalo Pinheiro, fundaram ou dirigiram periódicos no Brasil. 
João José Vaz, formado em Artes pela Academia de Belas Artes de Lisboa (1878), teve sua atuação profissional concentrada na pintura clássica, compondo telas e ambientes de teatros, mosteiros e palácios em Portugal, majoritariamente à convite do poder público, para além de sua participação na imprensa luso brasileira; atuou ainda como professor e diretor da Escola Industrial Afonso Domingues e da Escola Industrial de Setúbal, ambas portuguesas. Manoel Bordalo Pinheiro, filho de Rafael Bordalo Pinheiro, colaborou com os investimentos iniciais de Pontos nos ii (1885-1891) e d'A Paródia (1900-1907), desempenhando ao lado de seu pai a função de diretor desses periódicos; colaborou com outras revistas ilustradas, em sua maioria também portuguesas, e, assim como Vaz, desempenhou função no magistério, sendo professor de desenho nas Escolas Industriais Rodrigues Sampaio e Fonseca Benevides, todas lusas.

À exceção de Antonio Leal, formado no Curso Normal para atuar como professor de educação básica, todos os outros estudaram desenho. Nesse sentido, destaca-se a trajetória de Alfredo Candido, cujo contexto de imigração para o Brasil relaciona-se aos processos de "remodelação urbana" da cidade do Rio de Janeiro, levados à cabo pelo então prefeito Pereira Passos: filho de "construtor", seu pai fora chamado ao Brasil, em 1904, para trabalhar nas reformas em curso (LIMA, 1963: 1133). Já tendo colaborado com a revista Brasil-Portugal desde 1900, funda no Rio de Janeiro a revista A Larva (1902-1903), "uma publicação de crítica excessivamente virulenta ao governo de Rodrigues Alves [então presidente do Brasil]" (LIMA, 1963: 1134). A Larva teria servido, em muitos aspectos, de inspiração para o posicionamento editorial d'O Malho, além de ter sido um primeiro termômetro de audiência, junto ao público, no que diz respeito à sátira política e à narração humorística do cotidiano das instituições públicas.

Julião Machado foi o proprietário com maior número de jornais em circulação na imprensa ilustrada carioca que, de maneira geral, apresentavam alto custo de produção, impressão em papel importado e circulação restrita às elites (FONSECA, 2016). Com passagem pelo Pontos nos iis, de Rafael Bordalo Pinheiro, e dos periódicos A Cigarra e A Bruxa - sob o patrocínio de Olavo Bilac, o que permitiria sua inserção "nas rodas intelectuais do Rio" (LIMA, 1963: 989) -, a construção de influência de Julião Machado sobre o espaço da caricatura nacional incide tanto sobre a importação de tecnologias de impressão quanto sobre a evidenciação das hierarquias sociais relativas aos processos de internacionalização. Tendo passado por cerca de dez 
periódicos portugueses antes de seu ingresso no Brasil em 1895, a formação escolar em Paris o habilita a uma posição privilegiada entre os pares (LIMA, 1963: 1072).

Vasco Lima fundou e dirigiu duas revistas no Brasil, sendo uma delas dedicada ao público infantil - segmento ainda pouco explorado na imprensa brasileira naquele momento. Em 1954, fora condecorado pelo Sindicato dos Jornalistas do Rio de Janeiro como Decano da Imprensa Carioca. A maior contribuição de Antonio Leal, por sua vez, fica por conta da abertura de uma das primeiras oficinas de fotografia da cidade do Rio, que atendia tanto pedidos empresariais (sobretudo ilustração de jornais e propagandas publicitárias), como particulares (cerimoniais, retratos de família etc.); com frequência, seu trabalho era anunciado na revista $O$ Malho. Todos eles participaram também, pelo menos uma vez, da Exposição Geral de Belas Artes no Rio de Janeiro e do Salão dos Humoristas, seja no Brasil ou em Portugal.

Rafael Bordalo Pinheiro, ícone das ilustrações portuguesas, é figura importante nesse arranjo, já que atuou, para além da esfera da imprensa lusitana, em publicações francesas, britânicas, espanholas, tendo sua experiência profissional partilhada entre folhetins e revistas ilustradas. No Brasil, em paralelo, fora tutor, empregador ou colega de tantos outros desenhistas da revista $O$ Malho, fazendo ponte para a importação de técnicas de desenho e impressão, assim como de modelos estéticos, gráficos, de linguagem etc., como argumentamos na seção anterior deste artigo.

Nesse sentido, se estabelecermos como critério da conexão entre os agentes, a passagem por um mesmo periódico, a influência de Rafael Bordalo Pinheiro sobre o espaço da caricatura brasileira aparece mediada por outros portugueses (João José Vaz, Alfredo Candido e Julião Machado) e pelo italiano Angelo Agostini, o qual, segundo Herman Lima (1963: 998), teria sido, junto a Bordalo Pinheiro, tutor daqueles que seriam enquadrados como os primeiros caricaturistas de renome no país, aparecendo uma geração mais tarde: Raul Pederneiras, Calixto Cordeiro (K. Lixto) e José Carlos de Brito Cunha (J. Carlos), todos os três tendo assumido cargos de direção na revista $O$ Malho, nos anos de 1910 e 1920. 


\section{Gráfico 2: Rede de interação dos agentes d'O Malho}

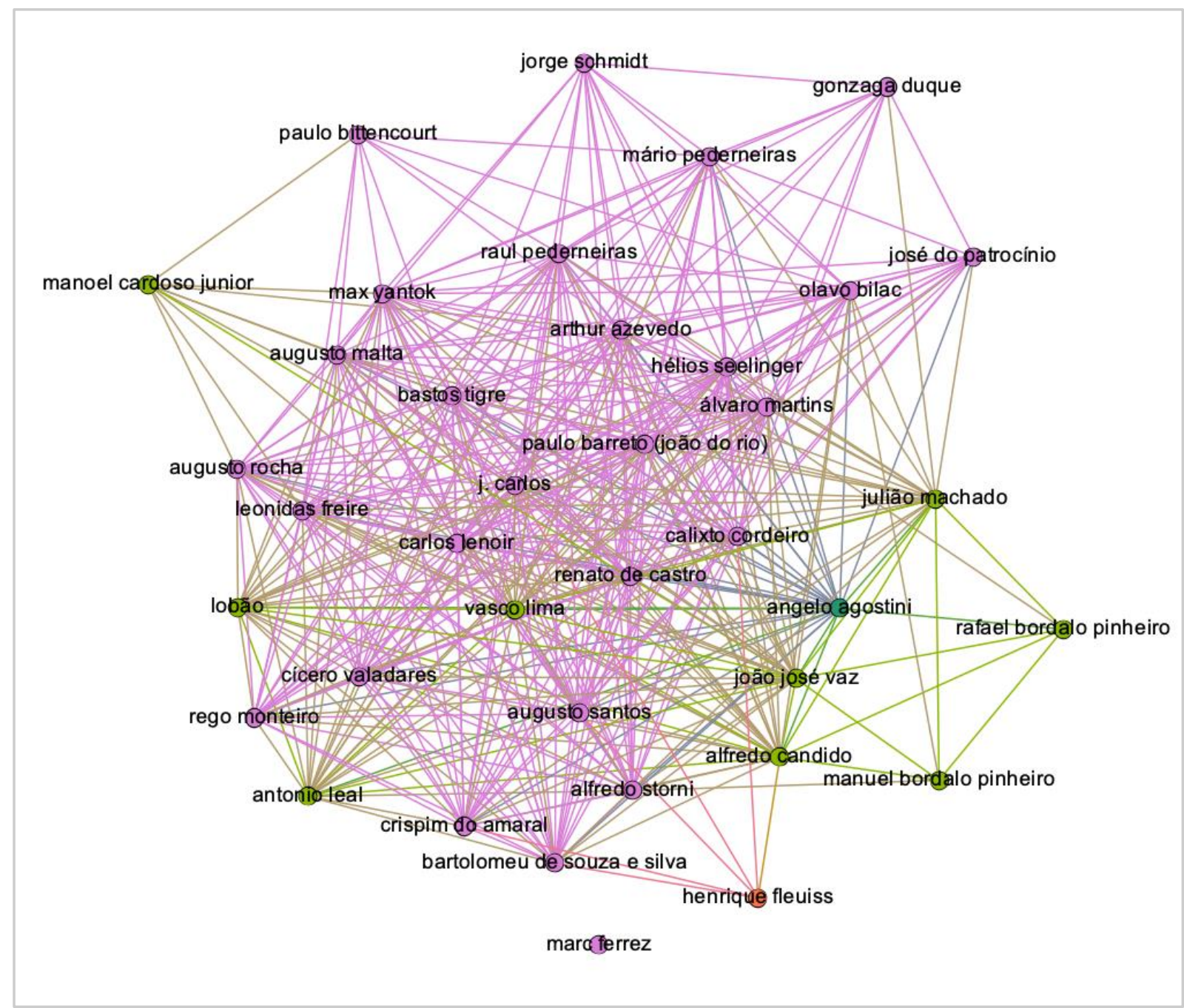

Elaboração dos autores. Software Gephi.

\section{4}

Para complementar as redes de circulação dos agentes, associamos aos dados de trajetórias características relativas à produção de discurso na revista $O$ Malho dentro do período das reformas urbanas da cidade do Rio de Janeiro (setembro de 1902 a dezembro de 1906): a) ano de produção/publicação (única variável ilustrativa); b) tipo: charge, fotografia ou documento/plano de obras; c) localização dentro da revista: capa, início, meio ou fim do exemplar; d) função: imagem descritiva ou alegórica; e) questão: política, infraestrutura, economia, saúde ou cultura; f) referência explícita ou não a ruas ou regiões específicas da cidade do Rio (“cid+" ou "cid-"); g) personagens retratados e suas respectivas legendas; h) diagramação: página inteira (“1”), meia página (“1/2”), um terço de página (“ $1 / 3$ ”) etc.; i) técnica: cores ou preto e branco (“PB”). A variável 
“personagens/legendas" divide-se em: a) autoridades políticas (“ap+" ou ap-”); b) representantes das classes populares (“cp+" ou "cp-"; c) representantes da pequena burguesia ("pb+" ou "pb-"; d) intelectuais ("int+" ou "int-"; e) animais ("ani+" ou "ani"; f) representantes da imprensa (“imp+" ou "imp-"; g) prédios públicos, vias e/ou estabelecimentos comerciais ("pred+" ou "pred-"; h) representantes do capital privado (“emp+" ou “emp-"); i) instituições públicas (“inst+" ou "inst-"). À questão da autoria ("aut+" ou "aut-") estão ligadas as variáveis de nacionalidade ("bras", se brasileiro; "estr", se estrangeiro) e o cargo ocupado dentro da revista ("chef", se chefia ou cargo administrativo, "cart" se cartunista, "fotog" se fotógrafo). Compuseram a amostra 682 imagens, dispostas em 224 exemplares e extraídas dos acervos de periódicos da Fundação Casa de Rui Barbosa (FCRB) e da Fundação Biblioteca Nacional (FBN) ${ }^{18}$.

Em termos gerais, a ACM descreve as imbricações entre um grande número de indivíduos e suas variáveis (classificadas em categorias e subsequentes modalidades) por meio de medidas espaciais como a distância euclidiana e a dispersão ao longo de eixos principais no plano cartesiano, fazendo com que seja possível reconstruir indutivamente as principais oposições entre conjuntos de práticas sociais e seus agentes (DUVAL, 2013). Nesse sentido, temos que: $61 \%$ das imagens publicadas no período foram charges, contra $34,7 \%$ de fotografias; $4,3 \%$ de seu conteúdo fazia referência a outras ilustrações de cunho descritivo, como a divulgação de planos de obras, plantas ou projetos arquitetônicos e reprodução ilustrada de retratos de personalidades políticas. À figura do Zé Povo, presente em 33,5\% das publicações e representada no gráfico pela sigla das "classes populares", associam-se com frequência representações de animais, temas políticos vinculados diretamente à cidade do Rio de Janeiro ou ao contexto nacional e a assinatura de cartunistas estrangeiros; o arranjo dessas variáveis aparece indicado no gráfico com destaque em vermelho.

\footnotetext{
18 Acervos disponíveis respectivamente em: <http://omalho.casaruibarbosa.gov.br/> e <http://memoria.bn.br/>. Último acesso: 13/03/19, às $11 \mathrm{~h} 42$.
} 


\section{Gráfico 3: Estrutura do espaço de produção das imagens d'O Malho}

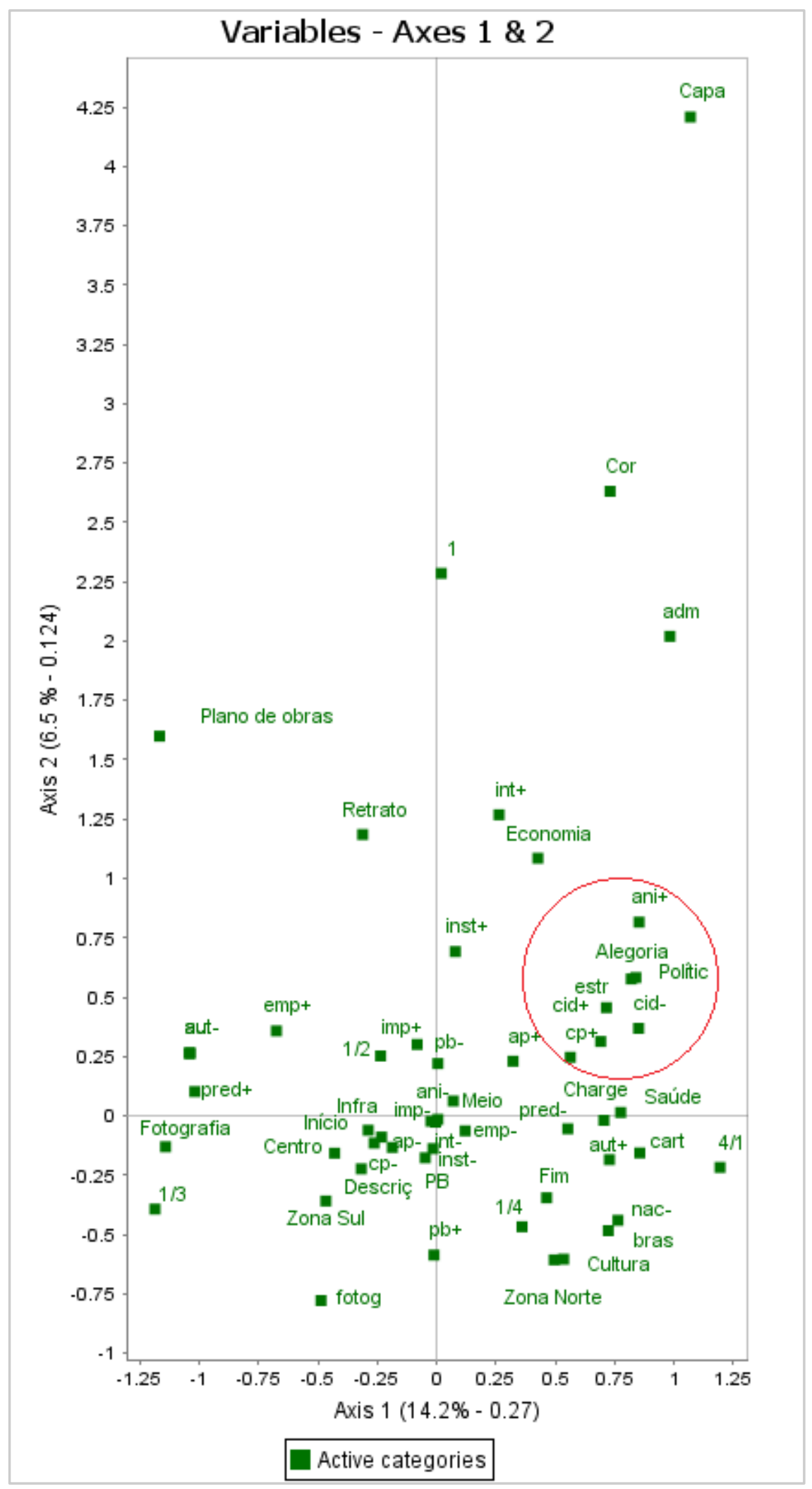

Elaboração dos autores. Software Coheris SPAD.

Destacam-se como contribuições ao eixo 1, as imagens do tipo fotografia e a autoria geral das publicações; no eixo 2, as regiões geográficas da cidade retratadas na 
revista, a técnica empregada na produção das imagens e a nacionalidade dos cartunistas - arranjo que, como argumentamos, se reflete na reprodução de Zé Povo. Constroem-se, assim, no quadro geral, evidências de uma oposição estrutural importante: a) grupo 1: fotografias (e, portanto, imagens descritivas) que retratam o centro da cidade e, em menor escala, a zona sul (áreas nobres) e a representação da pequena burguesia junto às obras públicas de maior impacto no projeto reformista; b) grupo 2: charges de caráter alegórico que versam sobre questões políticas, articulando personagens das classes populares às zonas da cidade menos privilegiadas e à presença de animais (normalmente burros ou tartarugas simbolizando a oposição atraso x progresso em comparação a bondes e redes elétricas). Uma aparente oposição entre a cidade reformada (grupo 1) e a cidade do atraso (grupo 2), cujo símbolo máximo de representação é a figura de Zé Povo.

\section{Considerações finais}

Característica peculiar da representação humorística nos séculos XIX e XX (SALIBA, 2002; FONSECA, 1999; SILVA, 1990), o desenho de ícones na composição dos estereótipos nacionais foi fenômeno global, a julgar pelas figuras de John Bull (Inglaterra), Miguel Alemão (Der Deutsche Michel, Alemanha), Tio Sam (Estados Unidos) etc. Originalmente sob a assinatura do português Rafael Bordalo Pinheiro, Zé Povo chega ao Rio de Janeiro em 1877, apenas dois anos depois de sua primeira aparição na revista ilustrada lisboeta Lanterna Mágica (1875). A difusão dessa personagem ascende e declina junto à circulação das revistas ilustradas no Brasil.

A ideia de uma nação "pequena", "indefesa", sujeita a invasões de nações "maiores", que emerge em Portugal logo após a Primeira Guerra Mundial em uma clara oposição ao poderio bélico, cultural e político da nação britânica (FREELAND, 1996: 78-79) - nesse sentido, uma "grande" e "forte" nação -, cria condições favoráveis não só para a recuperação na imprensa lusa daquele tempo das características apolíticas de Zé Povo, como também para o reforço delas na imprensa ilustrada brasileira. Isso faz com que, mesmo já nos anos 1900 e 1910, período de que tratamos neste texto, cerca de 40 anos depois da criação da personagem, as re-interpretações várias da figura de Zé Povo - ou Zé Povinho, propositadamente tratada no diminutivo - indiquem um projeto de manutenção das estruturas de "elites" que se desloca dos domínios da 
intelectualidade, aos domínios da arte e da política sob a face das identidades estratégicas de que dispunha o grupo dos caricaturistas. Do mesmo modo, durante o período das reforma urbanas no Rio de Janeiro (1902-1906), Zé Povo fora retratado em $33,5 \%$ das publicações d' $O$ Malho, sendo frequentemente associado a animais representativos do atraso (burros, tartarugas) em contraposição ao progresso (bondes e redes elétricas).

Isso posto, importam, para definir as condições de difusão desse personagem na caricatura brasileira em fins do século XIX e início do século XX, tanto o contexto político da época, quanto a dinâmica de circulação de agentes (pintores, escritores, fotógrafos, caricaturistas). De um lado, o contexto impunha à imprensa uma posição central na divisão do trabalho de construção de uma ideia de nação - ideia esta posta em risco com a queda da monarquia e o consequente processo de descorporificação do poder (JURT, 2012: 472-481). De outro lado, era a circulação dos agentes e seus arranjos que compunham a estrutura de possibilidades de importação de uma figura originalmente portuguesa - concebida, portanto, em um diferente contexto geográfico, social e político - para o espaço artístico e intelectual brasileiro e sua consequente imposição como símbolo nacional.

Os espaços de circulação desses agentes, então, permitem compreender as dinâmicas de produção e difusão dessas imagens que surgem em Portugal, sob diretrizes estéticas francesas, mas que introduzem um novo ethos no cenário brasileiro. A cidade do Rio de Janeiro é palco central dessas disputas, uma vez que já reunia instâncias de consagração entre pares (das quais se destacam a Academia de Belas Artes, a Academia Brasileira de Letras e a Academia Brasileira de Imprensa), e para as quais também valiam as normas e balizas europeias.

A centralidade dos caricaturistas portugueses na análise de redes, dentre os quais se sobressaem Rafael Bordalo Pinheiro, Alfredo Candido, Julião Machado e Vasco Lima, apontam para a necessidade de uma análise conjunta de trajetórias biográficas à luz de uma abordagem prosopográfica, uma vez que os cruzamentos de seus percursos escolar e profissional reforçam os condicionantes institucionais para além da construção de uma teia de relações de lealdade entre eles. Alternando-se entre as posições de fundador/proprietário, diretor e colaborador de revistas ilustradas em Portugal e no Brasil, tendo algumas inclusive dupla sede nas cidade de Rio de Janeiro e Lisboa, esse grupo de caricaturistas impunha aqui, sobre as disputas de formato, linguagem gráfica, critérios de excelência qualidade e de gosto, normas bastante próximas àquelas que 
vigoravam na Europa. O que fragiliza o argumento comumente explorado pelos estudos da história da imprensa de que a imagem entendida como conteúdo noticioso tivera, no Brasil, função democratizante e emancipatória.

\section{Fontes}

Correio da Manhã, abril de 1957. Acervo: Fundação Biblioteca Nacional.

Lanterna Mágica, junho de 1875. Acervo: Hemeroteca de Lisboa.

O Malho, setembro de 1902 a dezembro de 1906. Acervo: Fundação Casa de Rui Barbosa.

\section{Referências bibliográficas}

BACOT Jean-Pierre (2002). Trois générations de presse illustrée au XIXe siècle. Une recherche en paternité. Réseaux. França, n. 111, pp. 216-234, jan./ago.

BAKHTIN, Mikhail (2010). A cultura popular na Idade Média e no Renascimento. São Paulo: Hucitec, 2010.

BARBOSA, Marialva (2010). História Cultural da Imprensa, Brasil: 1800-1900. Rio de Janeiro: Mauad. (2013). História da Comunicação no Brasil. Petrópolis: Vozes.

BOISSEVAIN, Jeremy (1979). Network Analysis: a Reappraisal. Current Anthropology. Estados Unidos, vol. 20, n. 2, pp.392-394.

BORDIGNON, Rodrigo (2014). "Elites" políticas e intelectuais no início da República (1891-1895). In: Anais do $38^{\circ}$ Encontro Anual da ANPOCS. Caxambu: Associação Nacional de Pós-Graduação e Pesquisa em Ciências Sociais. Disponível em: http://www.anpocs.com/index.php/encontros/papers/38-encontroanual-da-anpocs/gt-1/gt13-1/8944-elites-politicas-e-intelectuais-no-inicio-darepublica-1891-1895. Acesso: 16 jan. 2020.

(2016). As origens e o significado do regime republicano: interpretações em disputa. Anos 90. Brasil, vol. 23, n. 43, pp. 235-266.

BOTELHO, Tarcisio (2005). Censos e construção nacional no Brasil Imperial. Tempo Social. Brasil, v. 17, n. 1, pp. 321-341.

BOURDIEU, Pierre (2004). Coisas ditas. São Paulo: Brasiliense, 2004.

CARDOSO, Pedro (2008). A Lithos Edições de Arte e as transições de uso das técnicas de reprodução de imagens. Dissertação (Mestrado em História Social da Cultura). Pontifícia Universidade Católica do Rio de Janeiro, Rio de Janeiro.

CARVALHO, José Murilo (1987). Os bestializados: o Rio de Janeiro e a República que não foi. São Paulo: Companhia das Letras. (1990). A formação das almas: o imaginário da República no Brasil. São Paulo: Companhia das Letras, 1990.

(2008). A construção da ordem: a elite política imperial. Teatro de sombras: a política imperial. Rio de Janeiro: Civilização Brasileira.

CHALHOUB, Sidney (2012). A força da escravidão: ilegalidade e costume no Brasil Oitocentista. São Paulo: Companhia das Letras, 2012.

COELHO, Edmundo (1999). As Profissões Imperiais: Medicina, Engenharia e Advocacia no Rio de Janeiro (1822-1930). Rio de Janeiro: Record. 
DOS ANJOS, José Carlos (2003). Elites Intelectuais e a Conformação da Identidade Nacional em Cabo Verde. Estudos Afro-Asiáticos. Brasil, v. 25, n. 3, pp. 579-596.

DUVAL, Julien (2013). L'analyse des correspondances et la construction des champs. Actes de la Recherche en Sciences Sociales. França, v. 5, n. 200, pp. 110-123.

FONSECA, Joaquim (1999). Caricatura: A imagem gráfica do humor. Porto Alegre: Artes e Ofícios.

FONSECA, Letícia (2016). Uma Revolução Gráfica: Julião Machado e as revistas ilustradas no Brasil, 1895-1898. São Paulo: Edgard Blücher.

FREELAND, Alan (1996). Zé Povinho and John Bull: Portuguese Perceptions of Britain, 1870-90. Portuguese Studies. Portugal, v. 12, pp. 78-88.

JURT, Joseph (2012). O Brasil: um Estado-Nação a ser construído. O papel dos símbolos nacionais, do Império à República. Mana. Brasil, v. 18, n. 3, pp. 471509.

KERR, David (2000). Caricature French political culture 1830-1848. Charles Philipon and illustrated press. Oxford: Clarendon Press.

KUSCHNIR, Karina (2001). Trajetória, projeto e mediação na política. In: VELHO, Gilberto; KUSCHNIR, Karina (Orgs.). Mediação, Cultura e Política. Rio de Janeiro: Aeroplano.

LIMA, Herman (1963). História da caricatura no Brasil III. Rio de Janeiro: José Olympio.

LINS, Vera (2010). Em revistas, o simbolismo e a virada de século. In: LINS, Vera; OLIVEIRA, Cláudia; VELLOSO, Monica (Orgs.). O moderno em revistas: representações do Rio de Janeiro de 1890 a 1930, pp. 15-41. Rio de Janeiro: Garamond.

LUCA, Tania Regina (2011). Leituras, projetos e (re)vista(s) do Brasil (1916-1944). São Paulo: Unesp.

(2017). A Ilustração (Paris, 1884-1892) e a Revista de Portugal (Porto, 18891892): diálogos entre projetos editoriais e possibilidades técnicas. Topoi. Brasil, v. 18, n. 34, pp. 91-115.

LUSTOSA, Isabel (1989). Humor e política na Primeira República. Revista USP. Brasil, v. 53, pp. 1-12.

(2000). Insultos Impressos: A guerra dos jornalistas na Independência (18211823). São Paulo: Companhia das Letras.

. (2005). Angelo Agostini, Julião Machado e o nascimento de uma caricatura brasileira. História Viva. Brasil, v. 34, pp. 84-87.

MARINGONI, Gilberto (2010). Angelo Agostini: A Imprensa Ilustrada da Corte à Capital Federal, 1864-1910. São Paulo: Devir Livraria.

MARTINS, Ana Lucia (2019). Julião Machado: arte gráfica exalando a tinta da impressão. Estudos Avançados. Brasil, v. 33, pp. 315-320.

; LUCA, Tania Regina (2008). História da Imprensa no Brasil. São Paulo: Ed. Contexto.

MEDINA, João (2005). Rafael Bordalo Pinheiro e o Zé Povinho, auto-caricatura do português. Linguas e Letras. Portugal, v. 6, n. 11, pp. 137-148.

MICELI, Sergio (2015). Intelectuais à brasileira. São Paulo: Companhia das Letras.

PAIVA, Clotilde; MARTINS, Roberto (1983). Um estudo crítico do Recenseamento de 1872. Relatório de pesquisa. Brasília: PNPE.

QUELUZ, Marilda (2012). As andanças de Zé: representações do povo nas revistas curitibanas de humor do início do século XX. Antíteses. Brasil, v. 5, n. 9, pp. 205231. 
RIBEIRO, Pedro (2010). Memórias de Zé Povo ou memórias individuais? - O povo na retórica da charge e a legitimação dos discursos políticos dos caricaturistas na imprensa carioca do início do século XX. In: Anais do XIV Encontro Regional Anpuh-Rio. Rio de Janeiro: Associação Nacional de História. Disponível em: http://www.encontro2010.rj.anpuh.org/resources/anais/8/1276642118_ARQUIVO _PedroKrause.pdf. Acesso: 16 jan. 2020.

RODARTE, Marcio; SANTOS JUNIOR, José Maria (2019). A estrutura ocupacional revisitada: uma proposta de correção dos dados do Recenseamento Geral do Império de 1872. In: Anais do XVI Encontro Nacional de Estudos Populacionais. Caxambu: Associação Brasileira de Estudos Populacionais. Disponível em: http://www.abep.org.br/publicacoes/index.php/anais/article/view/3390. Acesso: 16 jan. 2020.

SALIBA, Elias (2002). Raízes do Riso. A representação humorística na história brasileira: da Belle Époque aos primeiros tempos do rádio. São Paulo: Companhia das Letras.

SAPIRO, Gisèle (2006). Réseaux, institutions et champ. In: MARNEFFE, Daphné; DENIS, Benoît. Les réseaux littéraires. Bruxelles: Le Cri/CIEL.

SCHERER, Marta (2012). Imprensa e Belle Époque: Olavo Bilac, o jornalismo e suas histórias. Palhoça: Unisul.

SILVA, Marcos (1990). Caricata República: Zé Povo e o Brasil. São Paulo: Marco Zero.

SILVA, Rogério; ALMEIDA, Silvia (2013). Do (in)visível ao risível: o negro e a "raça nacional" na criação caricatural da Primeira República. Estudos Históricos. Brasil, v. 26, n. 52, pp. 316-345.

SILVERMAN, Sydel (1977). Patronage and Community-Nation Relationship in Central Italy. In: SCHMIDT, Steffen; GUASTI, Laura; LANDE, Carl; SCOTT, James. Friends, Followers and Factions. A reader in political clientelism. Berkeley: University of California Press.

TELLES, Angela (2010). Desenhando a nação - Revistas ilustradas do Rio de Janeiro e de Buenos Aires nas décadas de 1860-1870. Brasília: Funag.

VELLOSO, Monica (1995). A modernidade carioca na sua vertente humorística. Estudos Históricos. Brasil, v. 8, n. 16, pp. 269-278.

(2010). As distintas retóricas do moderno. In: LINS, Vera; OLIVEIRA, Cláudia; VELLOSO, Monica (Orgs.). O moderno em revistas: representações do Rio de Janeiro de 1890 a 1930, pp. 43-110. Rio de Janeiro: Garamond. . (2015). Modernismo no Rio de Janeiro: Turunas e Quixotes. Petrópolis: KBR.

VISCARDI, Cláudia; SOARES, Lívia (2018). Votos, partidos e eleições na Primeira República: a dinâmica política a partir das charges de O Malho. Revista de História. Brasil, v. 177, pp. 1-31.

Artigo recebido em 23 de janeiro de 2020.

Aprovado em 21 de junho de 2020.

DOI: 10.12957/intellectus.2020.47917 